\title{
KERAGAAN USAHA AYAM RAS PEDAGING DI KECAMATAN PARUNG BOGOR: PERBANDINGAN USAHATERNAK MITRA DAN USAHATERNAK MANDIRI
}

\author{
Suryani Nurfadillah" ${ }^{1)}$, dan Dwi Rachmina ${ }^{2)}$ \\ ${ }^{1,2)}$ Departemen Agribisnis, Fakultas Ekonomi dan Manajemen, Institut Pertanian Bogor \\ ${ }^{1)}$ suryani.nurfadillah@yahoo.com
}

\begin{abstract}
Broiler farming is one of the potential business, but this business has a high risk and requires substantial capital. One of the strategies that is used to overcome the problem is a partnership. Cogreg Village is one of the broiler producer areas in Bogor District. Most of the broiler farming in Cogreg are small and conventional farms. It is managed by a partnership which is different from broiler partnerships in general. The objectives of this study were to analyze the partnership and to compare the farm performance between partnership and independent broiler farm in Cogreg Village, Parung Subdistrict, Bogor Regency. This study used farm income analysis and $R$./C ratio method. The results showed that production, income, and the $R / C$ ratio of partnership member were higher than those of independent farmers on any scale. This proves that the partnership has a positive effect on broiler farming production and income. However, based on the qualitative analysis, it can be stated that the benefit sharing between farmers and firms is not balanced. The benefit received by the firm was much higher than that received by the farmer. The study recommends the need to establish a written partnership contract and improve maintenance management system, especially feed management.
\end{abstract}

Keyword(s): Broiler, farm income analysis, farm performance, partership, production

\begin{abstract}
ABSTRAK
Usaha ayam ras pedaging merupakan salah satu usaha yang potensial diusahakan namun membutuhkan modal yang besar dan rentan terhadap risiko. Desa Cogreg merupakan salah satu daerah penghasil ayam ras pedaging di Kabupaten Bogor yang kebanyakan usahanya berskala kecil dan masih diusahakan secara konvensional. Usahaternak ayam ras pedaging di Cogreg banyak dikelola secara kemitraan yang mekanisme pelaksanaannya berbeda dari kemitraan ayam ras pedaging pada umumnya. Tujuan dari penelitian ini adalah untuk menganalisis pelaksanaan dan membandingkan produksi serta pendapatan usaha dari budidaya ayam ras pedaging di Desa Cogreg-Parung-Bogor. Alat analisis yang digunakan adalah analisis pendapatan usahatani dan $\mathrm{R} / \mathrm{C}$ rasio. Hasil penelitian menunjukkan bahwa produksi, pendapatan, dan $\mathrm{R} / \mathrm{C}$ rasio peternak mitra lebih tinggi dibandingkan peternak mandiri pada setiap skala. Namun berdasarkan analisis kualitatif dapat dikatakan bahwa manfaat yang diterima peternak dan perusahaan tidak seimbang. Manfaat yang diterima perusahaan jauh lebih tinggi dibandingkan yang diterima peternak. Saran yang dapat dirumuskan dari hasil penelitian adalah perlu adanya perjanjian kemitraan atau kontrak tertulis dan perbaikan dalam manajemen pemeliharaan ternak, khususnya manajemen pakan.
\end{abstract}

Kata Kunci: Ayam ras pedaging, analisis pendapatan usahatani, keragaan usahatani, kemitraan, produksi 


\section{Latar Belakang}

\section{PENDAHULUAN}

Peternakan berperan dalam memenuhi kebutuhan pangan hewani serta turut berkontribusi dalam perekonomian nasional. Berdasarkan data Pusat Data dan Informasi Pertanian (Pusdatin) 2104 diketahui bahwa kontribusi peternakan terhadap PDB selalu mengalami peningkatan setiap tahunnya. Laju pertumbuhan PDB sektor peternakan tahun dari 2011 hingga 2013 sebesar 4,72 persen per tahun.

Usaha di bidang peternakan yang paling banyak dilakukan di Indonesia adalah usahaternak ayam ras pedaging. Total populasi ayam ras pedaging tahun 2013 sebanyak 1,34 miliar ekor dan pada tahun 2014 meningkat menjadi 1,48 miliar ekor (Kementrian Pertanian, 2014). Peningkatan populasi ayam ras pedaging merupakan respon dari permintaan daging ayam ras yang selalu meningkat

Konsumsi daging ayam ras terus meningkat dari tahun ke tahun. Pada tahun 2013, konsumsi daging ayam ras mencapai 4,03 kilogram per kapita per tahun. Selain itu daging ayam ras merupakan daging yang paling banyak dikonsumsi dibandingkan daging lainnya (Direktorat Jenderal Peternakan dan
Kesehatan Hewan, 2014). Faktor utama yang menyebabkan tingginya konsumsi daging ayam ras adalah harganya yang lebih murah dibandingkan daging lainnya.

Peningkatan konsumsi daging ayam ras disebabkan oleh kenaikan pendapatan per kapita, pertambahan penduduk, dan peningkatan pemahaman masyarakat mengenai pentingnya pemenuhan kebutuhan protein. Konsumsi daging ayam ras yang tinggi belum dapat diimbangi oleh ketersediaannya. Perbandingan antara konsumsi dan ketersedian daging ayam ras per kapita rumah tangga dapat dilihat pada Tabel 1.

Data pada Tabel 1 menunjukkkan bahwa ketersediaan daging ayam ras belum mencukupi kebutuhan konsumsi masyarakat Indonesia. Selisih dari konsumsi dan ketersediaan menjadi suatu peluang untuk mengusahakan ternak ayam ras pedaging. Selain karena masih adanya peluang usaha akibat gap antara konsumsi dan ketersediaan, daya tarik dari usahaternak ayam ras pedaging ini waktu pemeliharaan yang lebih singkat dibanding ternak lainnya sehingga menyebabkan perputaran modal yang cepat pula.

Pengusahaan ayam ras pedaging memang potensial untuk dikembangkan, namun usaha ini membutuhkan modal

Tabel 1. Perbandingan Konsumsi Daging Ayam Ras Rumah Tangga dengan Ketersediaan

\begin{tabular}{lrrrr}
\hline \multirow{2}{*}{ Variabel } & \multicolumn{4}{c}{ Konsumsi (kg/kapita/tahun) } \\
\cline { 2 - 5 } & $\mathbf{2 0 1 0}$ & $\mathbf{2 0 1 1}$ & $\mathbf{2 0 1 2}$ & $\mathbf{2 0 1 3}$ \\
\hline Konsumsi & 3,55 & 3,65 & 3,49 & 4,03 \\
Ketersediaan & 2,64 & 3,01 & 3,15 & 3,28 \\
Selisih & $-0,91$ & $-0,64$ & $-0,34$ & $-0,75$ \\
\hline
\end{tabular}

Sumber : Pusat Data dan Informasi Pertanian 2013 
yang cukup besar, baik modal investasi maupun modal operasional. Sementara itu pengusahaan ayam ras pedaging banyak dilakukan oleh peternak-peternak skala kecil yang memiliki keterbatasan modal. Keadaaan ini mendorong terbentuknya karakteristik pengusahaan ayam ras pedaging yang berpola kemitraan untuk memadukan kekuatan antara peternak kecil dan perusahaan/ peternak besar. Namun tidak semua peternak ayam ras menjalankan usahanya dengan pola kemitraan, melainkan ada yang tetap berusaha secara mandiri. Alasan paling umum yang mendasari peternak tidak menjalin kemitraan adalah tidak menginginkan adanya pembagian keuntungan (Pribadi, 2013; Situmorang, 2013).

Pengusahaan ayam ras pedaging tersebar di hampir seluruh wilayah Indonesia. Jawa Barat merupakan provinsi penghasil ayam ras pedaging tertinggi di Indonesia dengan laju produksi 5,07 persen setiap tahunnya. Produksi daging ayam ras Jawa Barat tahun 2013 mencapai 35,90 persen dari keseluruhan produksi Indonesia. Kabupaten Bogor merupakan sentra produksi daging ayam ras terbesar di provinsi Jawa Barat dengan proporsi sebesar 19,01 persen terhadap total produksi ayam ras pedaging di provinsi Jawa Barat (Dinas Peternakan Provinsi Jawa Barat, 2014).

Total produksi daging ayam ras di Kabupaten Bogor tahun 2013 sebesar 95.315,19 ton. Produksi daging ayam ras di Kabupaten Bogor tersebar di 40 kecamatan dengan rata-rata produksi per kecamatan sebesar 2.382,88 ton. Kecamatan Parung merupakan salah satu daerah produsen daging ayam ras dengan produksi di atas produksi rata-rata per kecamatan, yakni sebesar 4.694,18 ton (Dinas peternakan dan Perikanan Kabupaten Bogor, 2014).

\section{Perumusan Masalah}

Pengusahaan ayam ras pedaging membutuhkan dukungan modal yang besar. Modal investasi diperlukan untuk penyediaan lahan, pembangunan kandang, penyediaan peralatan kandang, dan pengurusan izin. Sedangkan modal operasional terbesar dikeluarkan untuk penyediaan pakan dan DOC. Pengusahaan ayam ras dengan kapasitas 3000 ekor memerlukan biaya investasi sebesar $\mathrm{Rp}$ 85 juta rupiah dan biaya operasional per periode produksi sebesar 48 juta rupiah.

Selain kebutuhan modal yang besar, risiko yang dihadapi dalam pengusahaan ayam ras pedaging juga tinggi. Risiko yang dihadapi peternak ayam ras antara lain fluktuasi harga input terutama untuk pakan dan DOC, serangan penyakit yang meyebabkan peningkatan mortalitas dan penurunan produksi, serta fluktuasi harga jual ayam ras.

Salah satu strategi yang diterapkan untuk menanggulangi permasalahan permodalan dan risiko dalam pengusahaan ayam ras pedaging ini adalah dengan menjalin kemitraan (Andersson et al., 2005). Landasan kemitraan di Indonesia dijelaskan dalam Peraturan Pemerintah No. 44 tahun 1997 yang menyebutkan bahwa kemitraan adalah kerjasama usaha antara usaha kecil dengan usaha menengah dan atau dengan usaha besar disertai pembinaan dan pengembangan oleh usaha menengah dan atau usaha 
besar dengan memperhatikan prinsip saling memerlukan, saling memperkuat dan saling menguntungkan.

Pada kemitraan ayam ras pedaging terdapat perusahaan yang berkewajiban menyediakan sarana produksi berupa DOC, pakan, obat-obatan, sekam, dan lain-lain. Selain itu perusahaan juga melakukan pendampingan terhadap proses budidaya yang dilakukan oleh peternak plasma dan mengelola hasil produksi peternak baik dalam bentuk mengolah maupun memasarkan. Selain itu juga terdapat peternak mitra yang berkewajiban menyediakan tenaga kerja dan melakukan kegiatan budidaya.

Adanya pembagian peran dan tugas antara perusahaan dan peternak mitra akan meyebabkan adanya perbedaan keragaan pada usahaternak mandiri dan usahaternak mitra. Terjaminnya pasokan input dan berbagai teknologi serta pendampingan yang diberikan oleh perusahaan menyebabkan kelancaran dalam proses produksi ayam ras pedaging sehingga diduga produksi yang dihasilkan akan lebih baik. Produksi yang lebih tinggi dengan harga input dan output yang sama seharusnya akan menyebabkan pendapatan yang diterima peternak mitra lebih tinggi dibandingkan peternak mandiri.

Desa Cogreg merupakan desa dengan produksi ayam ras pedaging tertinggi di Kecamatan Parung. Produksi ayam ras pedaging Desa Cogreg menyumbang hampir 51 persen dari total produksi ayam ras Kecamatan Parung (Dinas Peternakan dan Perikanan Kabupaten Bogor, 2014). Pengusahaan ayam ras pedaging di Desa Cogreg banyak dijalankan dengan sistem kemitraan. Berdasarkan uraian diatas maka kemitraan yang terjalin antara antara perusahaan inti dan peternak mitra ayam ras pedaging di Desa Cogreg menjadi menarik untuk dikaji dan dibandingkan dengan usaha mandiri. Adapun perumusan permasalahan yang akan dikaji adalah :

1. Bagaimana pelaksanaan kemitraan ayam ras pedaging di Desa Cogreg, Kecamatan Parung, Kabupaten Bogor?

2. Bagaimana perbandingan keragaan usaha ayam ras pedaging pada pola kemitraan dan mandiri di Desa Cogreg, Kecamatan Parung, Kabupaten Bogor?

\section{Tujuan Penelitian}

Tujuan dari penelitian ini yaitu:

1. Mendeskripsikan pelaksanaan kemitraan ayam ras pedaging di Desa Cogreg, Kecamatan Parung, Kabupaten Bogor.

2. Membandingkan keragaan usaha ayam ras pedaging pada pola kemitraan dan mandiri di Desa Cogreg, Kecamatan Parung, Kabupaten Bogor.

\section{KERANGKA PEMIKIRAN}

Usahaternak ayam ras pedaging merupakan salah satu jenis usaha yang potensial untuk dilakukan karena perputaran modalnya yang cepat. Namun usahaternak ayam ras pedaging ini membutuhkan modal yang besar serta rentan terhadap risiko. Pengusahaan ayam ras pedaging di Indonesia dilakukan oleh peternak kecil atau peternak rakyat 
dan peternak besar yang biasanya berbentuk perusahaan.

Peternak kecil umumnya memiliki keterbatasan modal, adopsi teknologi yang rendah, skala usaha kecil, akses pasar sulit dan terbatas, dan kemampuan manajerial yang rendah. Namun biasanya peternak kecil memiliki keterampilan lebih tinggi yang didapatkan dari pengalaman beternak selama bertahuntahun. (Broadway, 2009; Brown et al., 2002; Ellis, 2005).

Di sisi lain karakteristik peternak besar adalah memiliki modal yang banyak, akses terhadap pasar dan teknologi, dan manajemen sudah teratur. Namun umumnya perusahaan atau peternak besar mengalami kekurangan sumberdaya untuk memenuhi pangsa pasar potensialnya. Sumberdaya yang dimaksud biasanya berupa tenaga kerja, lahan,dan kandang.

Kelebihan dan kekurangan dari kedua golongan peternak dapat dipadukan dengan kemitraan. Kemitraan adalah suatu strategi bisnis yang dilakukan oleh dua pihak atau lebih dalam jangka waktu tertentu untuk meraih keuntungan bersama dengan prinsip saling membutuhkan, saling menguntungkan, dan saling memperkuat. Kemitraan agribisnis dapat menjadi instrumen untuk meningkatkan produktivitas dan efisiensi, membagi risiko, dan mendapat jaminan bahan baku serta jaminan distribusi pemasaran (Coelli et al, 2002; Haji and Andersson, 2007; Hall, 2006; Susrusa dan Zulkifli, 2006). Perusahaan skala besar dapat beroperasi secara full capacity dengan memanfaatkan lahan dan tenaga kerja dari petani/peternak mitra. Peningkatan produktivitas bagi peternak biasanya dicapai secara dengan cara menambah input atau menggunakan teknologi yang lebih baik.

Kemitraan usahaternak ayam ras pedaging di Desa Cogreg Kecamatan Parung berbentuk kemitraan inti plasma. Kemitraan inti plasma merupakan pola hubungan kemitraan antara kelompok mitra usaha sebagai plasma dengan perusahaan inti yang bermitra. Menurut Hafsah (2000), melalui pola inti plasma akan tercipta saling ketergantungan dan saling memperoleh keuntungan, pemberdayaan peternak rakyat di bidang teknologi, modal, kelembagaan sehingga pasokan bahan baku dapat lebih terjamin dalam jumlah dan kualitas sesuai standar yang diperlukan, serta beberapa peternak rakyat yang dibimbing oleh inti mampu memenuhi skala ekonomi sehingga dapat dicapai tingkat efisiensi.

Kemitraan usahaternak ayam ras pedaging akan mempengaruhi aspek budidaya dan harga. Dengan adanya kemitraan pasokan sapronak atau input produksi akan terjamin dan penggunaan input juga berada dibawah pengawasan perusahaan inti. Keteraturan dalam pasokan dan penggunaan input diharapkan akan meningkatkan hasil produksi. Peningkatan hasil produksi akan meningkatkan penerimaan. Harga yang ditetapkan oleh perusahaan inti diharapkan juga dapat menguntungkan peternak mitra. Harga input akan mempengaruhi biaya produksi, sedangkan harga output akan mempengaruhi penerimaan. Besarnya penerimaan dan biaya akan mempengaruhi pendapatan usahaternak. 
Analisis yang digunakan untuk membandingkan pendapatan pada usahaternak ayam ras pedaging adalah analisis pendapatan usahatani. Pendapatan usahaternak diperoleh melalui selisih antara penerimaan dengan biaya-biaya usahaternak yang dikeluarkan, baik biaya tunai maupun biaya nontunai (biaya diperhitungkan). Setelah itu akan diketahui keuntungan relatif yang diperoleh melalui perbandingan analisis imbangan penerimaan dan biaya $(\mathrm{R} / \mathrm{C})$ pada peternak mitra dengan peternak nonmitra. Jika nilai $\mathrm{R} / \mathrm{C}$ rasio lebih dari satu, maka nilai tersebut menunjukkan bahwa usahaternak ayam yang dijalankan menguntungkan, dan sebaliknya. Kemitraan yang dijalankan berpengaruh positif terhadap pendapatan apabila nilai pendapatan dan $\mathrm{R} / \mathrm{C}$ rasio peternak mitra lebih tinggi dibandingkan peternak mandiri.

\section{METODE PENELITIAN}

\section{Lokasi dan Waktu Penelitian}

Penelitian ini dilaksanakan di Desa Cogreg, Kecamatan Parung, Kabupaten Bogor. Responden adalah peternak ayam ras pedaging baik yang bermitra maupun yang tidak bermitra (mandiri). Pemilihan lokasi penelitian dilakukan secara sengaja (purposive) karena lokasi tersebut merupakan salah satu sentra produksi ayam ras pedaging di Kabupaten Bogor yang memiliki karakteristik khas dibandingkan daerah sentra produksi lainnya.

Usahaternak ayam ras pedaging di Desa Cogreg umumnya berskala kecil dengan kapasitas di bawah 10.000 ekor dan proses produksi yang digunakan masih tergolong tradisional. Selain skalanya yang kecil dan proses produksinya yang masih tergolong tradisional, usahaternak ayam ras pedaging di Desa Cogreg banyak diusahakan dengan pola kemitraan. Kemitraan yang dijalankan di desa ini juga memiliki perbedaan dengan kemitraan ayam ras pedaging pada umumnya. Perbedaan yang paling utama adalah tidak adanya harga kontrak baik untuk input maupun hasil produksi. Pengumpulan data dilakukan pada pertengahan bulan Januari hingga Maret 2014.

\section{Jenis dan Sumber Data}

Data yang digunakan dalam penelitian ini terdiri dari data primer dan data sekunder. Data primer diperoleh melalui observasi dan wawancara terhadap responden dengan alat bantu berupa pengisian kuisioner. Wawancara dilakukan kepada pihak perusahaan inti serta peternak ayam ras pedaging, baik yang berternak secara mandiri maupun yang menjalin kemitraan. Data primer meliputi data faktor produksi, harga faktor produksi, biaya produksi, dan data penerimaan usahatani.

Data sekunder meliputi monografi Desa Cogreg, data produksi dan produktivitas, serta data konsumsi ayam ras pedaging. Data sekunder diperoleh dari informasi tertulis yang berasal dari literatur-literatur yang relevan sepeti buku, hasil penelitian terdahulu, informasi dari Dinas Peternakan, Badan Pusat Statistik, Perpustakaan IPB, dan instansi lain yang dapat membantu ketersediaan data.

\section{Pengumpulan Data}

Populasi dalam penelitian ini adalah seluruh peternak ayam ras pedaging baik 
yang mandiri maupun yang menjalin kemitraan dengan perusahaan inti. Peternak ayam ras pedaging yang menjalin kemitraan dengan perusahaan inti berjumlah 87 orang, sedangkan peternak mandiri berjumlah 6 orang. Dari populasi tersebut seluruh peternak mandiri dijadikan responden dan 30 orang peternak mitra dipilih secara acak (simple random sampling) untuk dijadikan sampel.

\section{Pengolahan dan Analisis Data}

Analisis kualitatif digunakan untuk menggambarkan data kualitatif seperti keragaan usahatani ayam ras pedaging, karakteristik lokasi penelitian, karakteristik responden, dan gambaran mengenai pelaksanaan kemitraan antara perusahaan inti dan peternak mitra ayam ras pedaging.

Analisis kuantitatif dilakukan dengan menggunakan analisis pendapatan usahatani untuk mengetahui pendapatan dan $\mathrm{R} / \mathrm{C}$ untuk mengetahui efisiensi biaya usahaternak ayam ras pedaging. Komponen pendapatan usahatani dan $\mathrm{R} / \mathrm{C}$ rasio dalam penelitian ini dianalisis dengan menggunakan perbandingan tiga skala pada masing-masing kelompok peternak, baik peternak mitra maupun peternak mandiri. Pengelompokan skala didasarkan pada kapasitas produksi peternak ayam ras pedaging. Karena variasi kapasitas produksi ayam per periode berkisar antara 2.000-8000 ekor ayam per peternak, maka skala usaha dibagi menjadi tiga katagori dengan proporsi kapasitas yang sama. Skala I merupakan peternak yang memiliki kapasitas produksi 2.000-4.000 ekor ayam dalam satu periode produksi. Peternak skala II memiliki kapasitas 4.001-6.000 per periode produksi. Sedangkan peternak skala III adalah yang memiliki kapasitas produksi 6.001-8.000 per periode produksinya. Analisis dengan menggunakan perbandingan ketiga skala ini ditujukan untuk mengetahui apakah ada perbedaan struktur biaya dan penerimaan yang dipengaruhi oleh skala usaha.

\section{KEMITRAAN AYAM RAS PEDAGING}

Sebagian besar usaha ternak ayam ras pedaging di Desa Cogreg diusahakan secara bermitra, pola kemitraan yang diterapkan mirip dengan Inti-plasma. Dimana ada perusahaan yang berperan dalam menyediakan sapronak, melakukan pembinaan, dan mengelola seluruh hasil produksi plasma, dan ada peternak mitra yang bertugas mengelola usahaternak untuk perusahaan. Peternak mitra tidak diperbolehkan menggunakan sapronak dari pihak lain serta menjual hasil panen ke pihak lain selain perusahaan.

Terdapat tiga perusahaan (inti) di wilayah Desa Cogreg yang yang menyediakan kerjasama ternak ayam ras pedaging. Ketiga perusahaan yang berbentuk CV (commanditaire vennootschap) tersebut menerapkan sistem bagi hasil kepada seluruh peternak mitranya. Perjanjian mengenai aturan atau mekanisme kemitraan yang diberlakukan oleh ketiga perusahaan tersebut juga sama. Perjanjian antara perusahaan dengan peternak plasma hanya dilakukan secara lisan, tidak ada kontrak tertulis yang sah secara hukum. 


\section{Penerimaan Peternak Mitra}

Perusahaan dan peternak mitra merupakan rekan kerja yang secara bersamasama menjalankan kewajiban masingmasing untuk mencapai tujuan bersama, dalam hal ini adalah maksimisasi profit. Peternak mitra mengharapkan perusahaan inti yang bersikap fair, sehingga mampu meningkatkan kesejahteraan peternak mitra. Begitu pula dengan perusahaan yang mengharapkan peternak berkualitas sebagai rekan bisnisnya.

Jumlah perusahaan yang lebih sedikit dibandingkan jumlah peternak yang ingin bermitra menyebabkan perusahaan dapat menentukan mana peternak yang akan menjadi mitranya. Selain itu terbatasnya kapasitas perusahaan untuk melayani peternak mitra juga menyebabkan diperlukannya seleksi calon peternak mitra. Sistem dan prosedur penerimaan mitra dilakukan secara informal namun sesuai tahapan-tahapan yang sudah menjadi kebiasaan.

Peternak yang ingin bergabung dalam kemitraan biasanya mengumpulkan informasi mengenai perusahaan yang menyediakan kemitraan. Informasi mengenai perusahaan inti dapat diperoleh dari teman sesama peternak, keluarga, maupun langsung dari perusahaan. Selanjutnya mereka akan memilih salah satu perusahaan inti yang sesuai dengan keinginan. Karena ketiga perusahaan di Desa Cogreg memiliki sistem dan aturan yang sama, biasanya calon peternak mitra memilih perusahaan yang paling dekat. Hal ini bertujuan untuk memudahkan berbagai urusan selama kemitraan berlangsung, seperti distribusi input, pengaduan masalah, dan pengontrolan rutin. Pemilihan perusahaan yang terdekat oleh calon peternak mitra biasanya juga disebabkan oleh telah terjalinnya hubungan baik sebagai tetangga diantara keduanya. Hal ini mengakibatkan calon peternak mitra akan merasa segan apabila bermitra dengan perusahaan lain yang lebih jauh.

Setelah menetapkan perusahaan yang diinginkan, calon peternak mitra akan langsung menemui pemilik atau atasan perusahaan untuk menyampaikan keinginannya bermitra dengan perusahaan tersebut. Kemudian pihak perusahaan akan menindaklanjuti dengan serangkaian proses seleksi. Aspek pertama yang akan menjadi bahan petimbangan dari perusahaan adalah pribadi calon peternak mitra, yang meliputi kejujuran, latar belakang keluarga, dan kehidupan bermasyarakat. Informasi mengenai kepribadian calon mitra tidaklah sulit didapat karena biasanya kedua pihak telah lama hidup bertetangga. Apabila track record calon peternak mitra baik, maka perusahaan akan melanjutkan ke tahap seleksi selanjutnya, yakni survei kandang.

Survei kandang merupakan salah satu tahap seleksi yang dilakukan dengan beberapa pertimbangan, diantaranya lokasi, kondisi, serta kelengkapan fasilitas kandang calon peternak mitra. Kandang peternak yang dapat dijadikan mitra minimal berkapasitas 1.000 ekor ayam. Kandang yang akan digunakan sebagai tempat produksi ayam ras pedaging haruslah milik calon peternak mitra sendiri yang dibuktikan dengan surat tanah. Hal ini ditujukan untuk meminimalisisr permasalahan dikemudian 
hari yang dapat mengganggu aktivitas produksi ayam ras pedaging, misalnya seperti sengketa tanah. Lokasi kandang yang disyaratkan adalah mudah dijangkau dan berada pada kawasan operasi perusahaan, yaitu wilayah Desa Cogreg. Keamanan lokasi dan kesediaan dari warga disekitar kandang juga menjadi bahan pertimbangan.

Berdasarkan proses survei kandang, maka pihak perusahaan akan menentukan layak atau tidaknya peternak tersebut bergabung sebagai mitra. Apabila layak, maka ditentukan pula berapa skala usahaternak sesuai dengan kapasitas kandang yang akan digunakan untuk menampung ayam dari perusahaan. Datadata mengenai hal tersebut kemudian dicatat dan kemudian disimpan dalam arsip perusahaan.

Setelah proses survei kandang selesai dan kandang dianggap layak, maka calon peternak mitra akan mendatangi perusahaan untuk membicarakan mekanisme kemitraan. Pembicaraan mengenai mekanisme kemitraan ini tidak berlangsung lama, karena calon peternak mitra sudah mengetahui mekanisme secara rinci dari rekan-rekan peternak yang sudah terlebih dulu menjalin kemitraan dengan perusahaan tersebut. Dalam pembicaraan ini, peternak mitra hanya menanyakan hal-hal yang kurang dimengerti saja serta menyerahkan persyaratan yang diminta perusahaan inti. Persyaratan tersebut adalah fotokopi KTP, kartu keluarga, dan surat tanah. Perusahaan di Desa Cogreg tidak ada yang mensyaratkan jaminan uang tunai kepada peternak mitranya. Apabila persyaratan sudah dipenuhi dan kedua pihak telah sepakat mengenai mekanisme kemitraan maka calon peternak mitra sudah sah menjadi mitra perusahaan.

\section{Penetapan Harga}

Sedikit berbeda dengan sistem kemitraan di daerah lain, sistem kemitraan ayam ras pedaging di Desa Cogreg tidak metapkan harga kontrak untuk input dan output. Harga yang digunakan oleh kedua belah pihak mengikuti harga pasar yang berlaku pada saat itu. Dengan mengikuti harga pasar berarti perusahaan tidak bersedia menanggung risiko harga, atau dengan kata lain risiko harga sepenuhnya ditanggung oleh peternak mitra. Hal ini tentunya sangat merugikan peterank mitra. Tidak adanya harga kontrak untuk input dan output ini turut menjadi salah satu alasan yang menyebabkan kemitraan usaha ayam ras pedaging di Desa Cogreg ini tidak termasuk pada pola kemitraan inti-plasma. Pada pola kemitraan intiplasma, perusahaan akan menanggung risiko harga dengan memberikan harga kontrak. Sebagai contoh, apabila harga ayam dipasar lebih rendah dibanding harga kontrak maka peternak akan dibayar sesuai dengan harga kontrak. Sedangkan apabila harga ayam di pasar lebih tinggi dibanding harga kontrak, maka peternak akan dibayar dengan harga pasar ataupun selisih harga pasar dan harga kontrak akan dibagi dua untuk peternak dan perusahaan. Dengan melakukan penetapan harga kontrak seperti itu berarti dalam kemitraan terlah terjadi risk sharing yang pro terhadap kesejahteraan peternak. 


\section{Pembinaan dan Pengawasan}

Peternak mitra mendapatkan pengawasan dari perusahaan melalui petugas penyuluh lapang (PPL). Pengawasan dilakukan untuk membantu peternak yang mengalami kesulitan dalam masa budidaya ternaknya. Pekerjaan yang dilakukan antara lain mengontrol pemeliharaan, melakukan penimbangan bobot ayam, serta membantu peternak menjaga kondisi kesehatan ayam. Perusahaan memiliki 46 PPL yang mendampingi peternak mitra. Pekerjaan sehari-hari PPL adalah mengunjungi peternak-peternak mitra secara bergantian.

\section{Bagi Hasil}

Kemitraan usaha ayam ras pedaging yang dilakukan di Desa Cogreg menuntut adanya sistem bagi hasil antara perusahaan dan peternak mitra. Perhitungan bagi hasil dilakukan setelah semua masa panen selesai dan semua ayam habis terjual. Bagi hasil dihitung dengan mengurangkan penerimaan dari penjualan ayam dengan biaya sapronak yang dikeluarkan perusahaan kemudian hasilnya selanjutnya di bagi dua. Sapronak yang masuk dalam perhitungan bagi hasil berupa DOC, pakan, obat-obatan, vitamin, skim, detergen, formalin, sekam, bahan bakar, dan kapur.

\section{Pelaksanaan Kemitraan}

Peternak mitra memang mendapatkan manfaat dalam hal peningkatan produktivitas dan efisiensi. Namun dalam hal penanggungan risiko, peternak mitra banyak dirugikan dibanding perusahaan khususnya untuk risiko harga. Hal ini dibuktikan dengan tidak adanya kontrak harga di awal perjanjian.

Pola kemitraan usaha ayam ras pedaging di Desa Cogreg tidak termasuk ke dalam kelima pola kemitraan yang diungkapkan Sumardjo et al. (2004). Secara sekilas kemitraan yang dijalankan memang mirip dengan pola inti-plasma. Namun pada pelaksanaannya, kemitraan yang dijalankan merupakan perpaduan antara pola inti-plasma dan dagang umum. Padahal pola inti-plasma dan dagang umum sangat bertolak belakang. Pola inti-plasma biasanya bertujuan untuk meningkatkan kesejahteraan petani atau peternak kecil dengan melakukan pembinaan dan pembagian penanggungan risiko, sedangkan pola dagang umum biasanya sangat berorientasi pada penjual dan profit.

Dikatakan seperti pola inti plasma karena ada perusahaan yang berperan dalam menyediakan sapronak, melakukan pembinaan, dan mengelola seluruh hasil produksi plasma, serta ada peternak mitra yang bertugas melakukan proses budidaya. Namun hal yang tidak sesuai dengan pola kemitraan inti plasma adalah lahan yang digunakan milik peternak mitra, tidak adanya harga kontrak dan perusahaan membawa tengkulak saat panen. Ketiga hal ini biasanya tidak dilakukan pada pola kemitraan intiplasma karena akan merugikan peternak mitra.

Sedangkan mirip pola dagang umum karena perusahaan awalnya merupakan sebuah poultry shop yang menjual berbagai kebutuhan sarana produksi ternak. Perusahaan yang juga merupakan poultry shop inilah yang menjadikan 
perjanjian kemitraan yang dibuat tidak menguntungkan peternak mitra. Perusahaan akan lebih berorientasi pada profit dari penjualan sapronak dibandingkan membina peternak mitra untuk meningkatkan kesesjahteraan mereka. Hal ini dibuktikan dengan harga input yang diterima peternak mitra lebih tinggi dibanding peternak mandiri. Selain itu dengan posisi perusahaan sebagi poultry shop, menimbulkan kesan bahwa kemitraan ini hanyalah suatu cara untuk mendapatkan pelanggan tetap bagi sarana produksi ternak yang dijualnya. Dengan menjalankan kemitraan seperti ini maka perusahaan akan lebih diuntungkan karena pasar sapronak sudah pasti, harga jual sapronak lebih tinggi, biaya yang dikeluarkan untuk membiayai peternak mitra terhitung lebih rendah dibandingkan apabila perusahaan harus membayar orang untuk mencari pasar, dan ditambah lagi dengan keuntungan dari bagi hasil kemitraan.

\section{Peternak Mandiri}

Budidaya ayam ras pedaging yang dilakukan peternak mandiri pada dasarnya sama dengan peternak mitra. Namun setiap setiap keputusan yang terjadi dalam usahaternak dibuat oleh peternak sendiri tanpa intervensi pihak lain. Peternak harus menyiapkan modal untuk investasi dan biaya operasional setiap periode. Selanjutnya segala keputusan selama proses budidaya, panen, dan memasarkan produk ditentukan peternak sendiri. Hal tersebut menyebabkan peternak tidak perlu berbagi keuntungan dengan pihak lain, akan tetapi seluruh risiko yang terjadi harus ditanggung oleh peternak sendiri. Peternak mandiri biasanya memiliki delapan siklus produksi selama satu tahunnya, sedangkan peternak mitra maksimal hanya memiliki enam siklus. Peternak mitra hanya memiliki enam siklus produksi dalam satu tahun karena perusahaan inti harus menyediakan sapronak secara bergilir dengan peternak mitra lainnya. Hal ini menyebabkan peternak mitra terkadang harus menunggu giliran mendapat pasokan sapronak walaupun kondisi kandang sudah siap untuk digunakan berproduksi kembali.

\section{BIAYA USAHATERNAK AYAM RAS PEDAGING}

Komponen biaya yang dikeluarkan dalam kegiatan usahaternak ayam ras pedaging terdiri atas dua, yaitu biaya tunai dan biaya tidak tunai atau biaya yang diperhitungkan. Selanjutnya biaya tunai dalam usaha ayam ras pedaging dikelompokkan menjadi biaya untuk sarana produksi utama (DOC, Pakan, dan Obat-obatan), biaya perlengkapan, dan biaya tenaga kerja luar keluarga. Biaya diperhitungkan meliputi biaya sewa lahan, biaya penyusutan kandang, biaya penyusutan peralatan, dan biaya tenaga kerja dalam keluarga. Seluruh komponen alisis pendapatan usahaternak (penggunaan input, biaya, penerimaan, dan pendapatan) dianalisis per 1.000 ekor ayam masuk.

\section{Biaya Tunai}

\section{Biaya DOC}

Rata-rata harga beli DOC per ekor oleh peternak mitra skala I, II, dan III 
berturut-turut sebesar Rp 4.405,56; Rp 4.422,22; dan Rp 4.300,00. Sedangkan harga beli DOC rata-rata oleh peternak mandiri skala I sebesar Rp 4.066,67 dan skala II sebesar Rp 4.166,67 per ekor. Biaya yang dikeluarkan untuk DOC adalah yang terbesar kedua setelah pakan yakni mencapai lebih dari 25 persen dari total biaya.

\section{Biaya pakan}

Pengeluaran terbesar dari usahaternak ayam ras pedaging dialokasikan untuk pembelian pakan. Peternak ayam ras pedaging di Desa Cogreg tidak menggunakan pakan starter dan finisher, melainkan hanya menggunakan satu jenis pakan selama masa pemeliharaan. Pengeluaran untuk pembelian pakan mencapai lebih dari 50 persen dari total biaya.

Peternak mandiri skala III menggunakan pakan dengan jumlah terbanyak, yakni $1.554,17 \mathrm{~kg}$ per 1000 ekornya. Sedangkan peternak dengan penggunaan pakan terhemat adalah peternak mitra skala I dengan jumlah pakan yang digunakan sebanyak $1.368,45 \mathrm{~kg}$ per 1.000 ekor. Berdasarkan analisis penggunaan input, diketahui bahwa semakin besar skala usaha, penggunaan pakan justru semakin boros. Hal ini dapat disebabkan oleh manajemen pemberian pakan yang tidak efisien, dimana banyak ditemukan pakan yang tercecer di sekitar kandang. Banyaknya pakan yang tercecer sering terjadi apabila ukuran kandang besar, atau peternak menggunakan lebih dari satu kandang. Manajemen pemberian pakan perlu diperbaiki supaya dapat menekan biaya produksi.

\section{Biaya obat-obatan}

Biaya penggunaan obat-obatan pada peternak mitra skala I, II, dan III berturutturut sebesar Rp 797.429,46; Rp 789.262,53; dan Rp 826.780,95; Sedangkan pada peternak mandiri biaya obatobatan sebesar Rp 898.352,50 dan Rp $808.891,67$. Biaya penggunaan obatobatan pada peternak mandiri lebih tinggi padahal harga beli yang diterima masih lebih murah dibanding peternak mitra. Tingginya biaya obat-obatan pada peternak mandiri disebabkan oleh kuantitasnya yang lebih banyak.

Perkembangan dan kesehatan ayam pada peternakan mitra terus dikontrol secara teratur oleh petugas medis dari perusahaan inti. Dosis dalam pemberian obatan-obatan pun relatif lebih tepat dibandingkan pada peternakan mandiri. Hal inilah yang menjadi penyebab jumlah obat-obatan yang digunakan peternak mitra dapat lebih kecil dibanding peternak mandiri.

\section{Biaya input penunjang dan PBB}

Input penunjang atau perlengkapan yang digunakan dalam usahaternak ayam ras pedaging adalah detergen, formalin, sekam, kayu bakar, kapur, dan listrik. Komponen biaya perlengkapan yang paling besar adalah kayu bakar, yaitu 41.94 persen pada peternak mitra dan 54.37 persen pada peternak mandiri. Komponen perlengkapan dengan biaya terbesar kedua adalah sekam, kemudian diikuti oleh listrik, perlengkapan pembersihan kandang (detergen, formalin, dan kapur) dan PBB. Rata-rata harga per satuan yang diterima oleh peternak mitra untuk keenam komponen perlengkapan 
tersebut lebih tinggi dibandingkan peternak mandiri.

\section{Biaya tenaga kerja luar keluarga (TKLK)}

Upah tenaga kerja untuk usaha ayam ras pedaging di desa ini adalah sebesar $\mathrm{Rp}$ 350 per ekor ayam masuk, sehingga biaya tenaga kerja luar keluarga untuk kapasitas 1.000 ekor adalah Rp 350.000,00. Upah tersebut dibagi untuk seluruh tenaga kerja luar keluarga, bukan untuk masingmasing tenaga kerja. Karena peternak mitra tidak menggunakan tenaga kerja luar keluarga maka seluruh biaya tenaga kerja tersebut untuk TKDK atau masuk dalam biaya diperhitungkan. Peternak mandiri umumnya menggunakan tenaga kerja luar keluarga untuk pemeliharaan ayam sehingga biaya TKLK yang harus dibayarkan per 1.000 ekor ayam adalah sebesar Rp 35.000,00. Rata-rata biaya TKLK pada skala II sebesar Rp 233.333,33 atau 1.49 persen dari biaya total dan biaya TKLK pada skala III sebesar Rp 350.000,00 atau 2.16 persen dari biaya total.

\section{Biaya Diperhitungkan}

Biaya diperhitungkan adalah biaya yang tidak dikeluarkan secara tunai namun patut diperhitungkan karena digunaka merupakan barang ekonomi (terbatas). Komponen biaya diperhitungkan dalam usahaternak ayam ras pedaging adalah sewa lahan, penyusutan kandang dan peralatan, serta tenaga kerja dalam keluarga.

\section{Biaya sewa lahan}

Seluruh peternak ayam ras pedaging di Desa Cogreg menggunakan lahan sendiri untuk menjalankan usahaternaknya. Biaya sewa lahan yang digunakan di sini diasumsikan untuk setiap peternak yakni sebesar 75 juta rupiah per hektar per tahun. Berdasarkan hal tersebut perbedaan biaya diperhitungkan atas sewa lahan yang dibebankan kepada peternak didasarkan luas lahan dan jumlah periode produksi per tahun, dimana peternak mitra hanya berproduksi $6 \mathrm{kali}$ dalam setahun sedangkan peternak mandiri 8 kali.

Lahan yang digunakan per 1.000 ekor ayam pada peternak mandiri lebih luas dibanding peternak mitra. Biaya sewa lahan per 1.000 ekor ayam yang tertinggi dimiliki oleh peternak mitra skala II, yakni sebesar Rp 90.285,49 per periode produksi. Sedangkan biaya sewa lahan terendah terdapat pada peternak mitra skala III, dengan biaya sebesar Rp $68.861,61$ per periode.

\section{Biaya penyusutan kandang dan peralatan}

Luas kandang yang digunakan untuk memelihara ayam sebanding dengan lahan yang tersedia. Luas kandang terbesar untuk memelihara 1.000 ekor dimiliki oleh peternak mandiri skala III, kemudian peternak mandiri skala II dan peternak mitra skala II. Seperti halnya biaya sewa lahan, biaya penyusutan kandang terbesar terdapat pada peternak mitra skala II yakni sebesar Rp 154.660,15. Sedangkan biaya penyusutan kandang yang paling kecil terdapat pada peternak mitra skala III yang hanya sebesar Rp 96.011,90 per periodenya.

Biaya penyusutan peralatan antara peternak mandiri skala II dan III tidak 
berbeda jauh. Dimana penyusutan kandang pada skala II sebesar Rp 50.873,29 dan skala III sebesar Rp 51.234,29. Sedangkan biaya penyusutan peralatan pada peternak mitra variasinya cukup tinggi yakni antara Rp 45.290,00 Rp 60.005,85.

\section{Tenaga kerja dalam keluarga (TKDK)}

Tenaga kerja dalam keluarga (TKDK) digunakan oleh hampir seluruh peternak ayam ras pedaging di Desa Cogreg. Bahkan seluruh aktivitas dalam usahaternak ayam milik peternak mitra dikerjakan oleh tenaga kerja keluarga. Hal ini berarti tidak ada uang tunai yang dikeluarkan untuk membayar upah tenaga kerja.

Upah tenaga kerja dalam keluarga diasumsikan sama seperti tenaga kerja luar keluarga, yaitu Rp 350,00 per ekor ayam masuk. Biaya TKDK per 1.000 ekor ayam pada peternak mitra skala I, II, dan III sama, sebesar Rp 350.000.00, walaupun jumlah $\mathrm{HOK}$ pada masingmasing skala berbeda.

Sedangkan pada peternak mandiri, biaya TKDK didasarkan pada HOK TKDK. Penggunaan TKDK pada peternak mandiri skala II lebih besar dibandingkan skala III. Biaya TKDK pada peternak mandiri skala II sebesar Rp 177.457 dan pada skala III sebesar Rp 38.722 .

\section{Produksi Usahaternak Ayam Ras Pedaging}

Total produksi peternak mitra skala I, II, dan III masing-masing sebesar $1.307,49 \mathrm{~kg} ; 1.210,35 \mathrm{~kg}$, dan $1.270,35$ kg. Sedangkan pada peternak mandiri skala II total produksinya sebesar $1.186,58 \mathrm{~kg}$ dan skala III sebesar $1.178,35 \mathrm{~kg}$. Rata-rata produksi peternak mandiri dibawah rata-rata produksi peternak mitra pada setiap skalanya. Peternak mandiri cenderung menjual sebagian besar hasil produksinya pada bobot rendah dengan tujuan mendapat harga yang lebih tinggi dan mengurangi penggunaan pakan. Produksi rata-rata per 1.000 ekor ayam pada peternak mitra dan mandiri dapat dilihat pada Lampiran 3.

\section{Penerimaan Usahaternak Ayam Ras Pedaging}

Penerimaan usahaternak ayam ras pedaging digolongkan menjadi penerimaan tunai dan penerimaan yang diperhitungkan. komponen penerimaan tunai adalah penerimaan dari hasil penjualan ayam dan kotoran. Penerimaan yang diperhitungkan adalah nilai dari hasil produksi yang bukan dalam bentuk uang. Penerimaan diperhitungkan di sini biasanya merupakan nilai dari ayam yang dikonsumsi sendiri, maupun di bagibagikan.

Penerimaan tunai dari penjualan ayam didapatkan dari perkalian harga dan berat ayam. Harga ayam per kilogram berbeda-beda sesuai dengan beratnya, semakin berat maka harganya semakin murah.

Penerimaan total usahaternak ayam ras pedaging merupakan jumlah dari penerimaan tunai dan penerimaan yang diperhitungkan. Penerimaan tunai yang utama berasal dari penjualan ayam. Penerimaan dari penjualan ayam yang tertinggi diterima oleh peternak mitra 
skala I dengan nilai penjualan sebesar Rp 22.057.373,08 dan penerimaan terendah diterima oleh peternak mandiri skala II sebesar Rp 22.062.351,25.

Penerimaan tunai lainnya didapatkan dengan menjual sekam bercampur kotoran sisa produksi. Setelah masa panen selesai, peternak akan menjual kotoran secara borongan. Umumnya pembeli mengumpulkan dan mengemas seluruh sekam dan kotoran yang tersisa di dalam kandang sendiri, kemudian seluruhnya kotoran dihargai dengan harga tertentu. Kisaran harga jual kotoran dan sekam ini adalah Rp 57,27 - Rp 100,96 per kilogram.

Penerimaan diperhitungkan dalam usaha ayam ras pedaging ini adalah hasil produksi yang tidak dijual. Komponen penerimaan yang diperhitungkan tidak dimiliki oleh peternak mitra, hal ini disebabkan karena seluruh hasil produksi peternak mitra dikelola oleh perusahaan inti. Nilai penerimaan yang diperhitungkan pada peternak mitra skala II sebesar Rp 69.966,67 dan skala III sebesar Rp 68.495,00.

Penerimaan total tertinggi diterima oleh peternak mitra skala I, sedangkan yang terrendah diterima oleh peternak mandiri skala II. Penerimaan total per 1.000 ekor ayam pada peternak mitra dan mandiri dapat dilihat pada Lampiran 4 dan 5 .

\section{Pendapatan Usahaternak Ayam Ras Pedaging}

Pendapatan usahaternak adalah selisih antara penerimaan dengan pengeluaran dalam melakukan usahaternak ayam ras pedaging. Analisis pendapatan usahaternak ternak ayam ras pedaging terdiri dari pendapatan atas biaya tunai dan pendapatan atas biaya total. Pendapatan usahaternak atas biaya tunai merupakan selisih antara penerimaan total dengan pengeluaran tunai.

Pendapatan atas biaya tunai tertinggi dimiliki oleh peternak mitra skala I dengan besar pendapatan Rp 7.744.106,51 per periode per pengusahaan 1.000 ekor ayam. Pendapatan atas biaya tunai yang tinggi pada peternak mitra skala I disebabkan oleh total penerimaan yang tinggi serta biaya tunai yang rendah. Peternak mitra skala I juga memiliki R/C rasio tertinggi yaitu sebesar 1,53 yang berarti bahwa setiap satu rupiah yang dikeluarkan pada usahaternak ayam ras pedaging tersebut akan menghasilkan penerimaan sebesar 1,53 rupiah.

Pendapatan atas biaya tunai dan $\mathrm{R} / \mathrm{C}$ rasio terendah dimiliki oleh peternak mandiri skala III. Besarnya pendapatan peternak mandiri skala III adalah $\mathrm{Rp}$ 5.266.591,20 per periode per pengusahaan 1.000 ekor ayam dan besarnya $\mathrm{R} / \mathrm{C}$ rasio 1,33

Biaya total tentunya memiliki nilai yang lebih besar daripada biaya tunai. Hal ini akan menyebabkan pendapatan atas biaya total menjadi lebih kecil dibandingkan pendapatan atas biaya tunai. Pendapatan tertinggi per 1.000 ekor terdapat pada peternak mitra skala I dengan nilai pendapatan sebesar $\mathrm{Rp}$ 7.131.964,16, sedangkan kelompok dengan pendapatan terendah adalah peternak mandiri skala III dengan nilai pendapatan $\mathrm{Rp}$ 4.986.360,30

Berdasarkan nilai $\mathrm{R} / \mathrm{C}$ rasio atas biaya total dapat disimpulkan bahwa 
pengusahaan ayam ras pedaging oleh peternak mitra dan peternak mandiri masih menguntungkan pada seluruh skala usaha walaupun nilainya lebih kecil dibanding $\mathrm{R} / \mathrm{C}$ rasio atas biaya tunai. Pengusahaan ayam ras yang paling menguntungkan dilakukan oleh peternak mitra skala I dengan $\mathrm{R} / \mathrm{C}$ rasio sebesar 1,47, yang berarti bahwa setiap satu rupiah biaya yang dikeluarkan untuk usahaternak ayam ras akan menghasilkan penerimaan sebesar 1,47 rupiah. Sedangkan kelompok dengan $\mathrm{R} / \mathrm{C}$ rasio yang paling kurang menguntungkan adalah peternak mandiri skala III dengan $\mathrm{R} / \mathrm{C}$ rasio sebesar 1,31.

Secara umum rata-rata pendapatan tunai dan pendapatan total pada kelompok peternak mitra lebih tinggi dibanding peternak mandiri. Apabila dibandingkan dengan skala yang sama antara peternak mitra dan peternak mandiri juga diperoleh bahwa pendapatan peternak mitra lebih tinggi dibanding peternak mandiri. Hal ini mengindikasikan bahwa kemitraan berpengaruh positif terhadap pendapatan usahaternak ayam ras pedaging di Desa Cogreg, Kecamatan Parung.

$\mathrm{R} / \mathrm{C}$ rasio peternak mitra lebih tinggi dibanding peternak mandiri, bahkan bila keduanya dibandingkan pada skala yang sama sekalipun. Hal ini menunjukkan bahwa kemitraan akan meningkatkan keuntungan relatif dari usahaternak ayam ras pedaging. Setiap satu rupiah biaya yang dikeluarkan oleh peternak yang bermitra akan menghasilkan penerimaan yang lebih tinggi dibandingkan peternak mandiri.
Kemitraan usaha ayam ras pedaging yang dilakukan di Desa Cogreg menuntut adanya sistem bagi hasil antara perusahaan dan peternak mitra. Bagi hasil menyebabkan pendapatan yang diterima peternak mitra jauh lebih kecil dibandingkan peternak mandiri. Diantara kelompok peternak mitra, skala I menerima pendapatan yang paling tinggi yaitu sebesar Rp 3.776.016,94 sedangkan yang paling rendah adalah skala II sebesar Rp 3.038.690,15 per siklus produksi.

Apabila diasumsikan peternak meminjam uang ke bank untuk mengadakan sendiri sapronak yang selama ini dipasok oleh perusahaan maka peternak harus meminjam uang rata-rata 88 juta rupiah per tahun. Dengan suku bunga sebesar 14 persen per tahun, berarti bunga yang harus dibayarkan sebesar 12 juta rupiah per tahun atau sekitar 2 juta rupiah per satu siklus produksi. Nilai ini jauh lebih kecil dibandingkan bagi hasil yang oleh perusahaan sebagai bentuk dari bunga pinjaman pengadaan sapronak. Asumsi apabila peternak mengambil kredit dari bank untuk menggantikan pengadaan sapronak dari perusahaan ini membuktikan bahwa selama ini perusahaan mengambil untung terlalu banyak dari pelaksanaan kemitraan usaha ayam ras pedaging di Desa Cogreg.

\section{SIMPULAN DAN SARAN}

\section{Simpulan}

Kemitraan pada usahaternak ayam ras pedaging di Desa Cogreg tidak dapat digolongkan pada kelima pola kemitraan yang ada. Kemitraan yang terjalin merupakan modifikasi dan perpaduan antara pola inti-plasma dan pola dagang 
umum. Kemitraan antara perusahaan inti dan peternak mitra menggunakan sistem bagi hasil (50:50) untuk perusahaan dan peternak mitra. Kemitraan ini dijalankan dengan berdasarkan kesepakatan antara kedua belah pihak tanpa adanya kontrak tertulis.

Berdasarkan hasil penelitian diperoleh bahwa produksi ayam ras pedaging pada usaha mitra lebih tinggi dibandingkan usaha mandiri pada masing-masing skala. Hasil analisis usahatani juga menujukkan bahwa pendapatan atas biaya tunai dan pendapatan atas biaya total total usaha mitra lebih tinggi dibanding usaha mandiri pada masingmasing skala usaha. Analisis $\mathrm{R} / \mathrm{C}$ rasio juga menunjukkan bahwa $\mathrm{R} / \mathrm{C}$ rasio usaha mitra lebih tinggi dibanding usaha mandiri yang berarti bahwa satu rupiah biaya yang dikeluarkan pada usaha mitra akan menghasilkan penerimaan yang lebih tinggi dibanding usaha mandiri.

Kemitraan yang dijalankan memang memberikan kemudahan-kemudahan bagi peternak dan menunjukkan pengaruh yang positif bagi produksi, pendapatan, dan $\mathrm{R} / \mathrm{C}$ rasio. Namun ditinjau dari pelaksanaannya, kemitraan ini lebih menguntungkan perusahaan dan merugikan peternak yang dibuktikan dengan tidak adanya harga kontrak sebagai bentuk dari risk sharing yang seharusnya ada dalam kemitraan, adanya ketentuan yang menyebutkan bahwa lahan dan kandang disediakan oleh peternak, serta adanya sistem bagi hasil untuk kedua belah pihak. Bagi hasil ini sangat menguntungkan perusahaan karena sebenarnya nilai tersebut sama dengan bunga kredit penyediaan sapronak. Besarnya keuntungan yang diterima perusahaan dari sistem bagi hasil ini dibuktikan dengan asumsi apabila peternak menyediakan sendiri sarana produksinya dengan meminjam melalui Kredit Usaha Rakyat (KUR).

\section{Saran}

1. Perusahaan dan peternak mitra perlu membuat perjanjian kemitraan atau kontrak tertulis yang disepakati oleh kedua belah pihak untuk memperjelas hak dan kewajiban keduanya. Dalam perjanjian kemitraan juga perlu adanya kontrak harga, baik harga input maupun output, sehingga risiko yang ditanggung kedua belah pihak lebih seimbang.

2. Peternak mandiri maupun peternak mitra bersama dengan perusahaan intinya perlu memperbaiki manajemen pemeliharaan ternak, khususnya manajemen dalam pemberian pakan. Pakan adalah komponen biaya yang terbesar. Apabila manajemen pemberian pakan dapat diperbaiki, maka dapat meningkatkan pendapatan usahaternak.

3. Berdasarkan hasil skenario penggunaan kredit dapat disarankan bahwa apabila peternak mitra memilih melakukan kemitraan karena tidak memiliki modal untuk menyediakan input maka akan lebih baik untuk menggunakan kredit dari bank dibandingkan menjalankan kemitraan dengan pola tersebut. Hal ini dikarenakan dengan meminjam maka pendapatan yang diterima peternak akan lebih tinggi. 


\section{DAFTAR PUSTAKA}

Andersson H, Larsén K, Lagerkvist CJ, Andersson C, Blad F, Samuelsson, J Skargren. 2005. Farm Cooperation to Improve Sustainability, AMBIO: A Journal of the Human Environment 34(4): 383-387.

Broadway M. 2009. Growing Urban Agriculture in North American Cities: The Example of Milwaukee. Focus on Geography 52(3), 23-30.

Brown K, Bailey M, Meares CA, Nasr J, Smit J, and Buchanan T. 2002. Urban Agriculture and Community Food Security in the United States: Farming from the City Center To the Urban Fringe. (P. Mann, Ed.), $1-30$

Coelli T, Rahman S. and Thirtle C. 2002. Technical, allocative, cost and scale Efficiencies in Bangladesh rice cultivation: a non-parametric approach. Journal of Agricultural Economics 53: 607-626.

[Disnak] Dinas Peternakan Provinsi Jawa Barat. 2014. Populasi Ternak Ayam di Provinsi Jawa Barat Tahun 2013. Bandung.

[Disnakan] Dinas Peternakan dan Perikanan Kabupaten Bogor. 2014. Produksi Ternak di Kabupaten Bogor Tahun 2013. Bogor.

[Ditjennak] Direktorat Jenderal Peternakan dan Kesehatan Hewan. 2014. Konsumsi Daging Segar Indonesia. Jakarta .

Ellis F. 2005. Small farm, livelihood diversification, and rural-urban transitions: Strategic issues in SubSaharan Africa. In The future of small farms. Research Workshop Proceedings, 135-149, Wye, U.K., June 26-29, 2005.

Hafsah MJ. 2000. Kemitraan Usaha Konsepsi dan Strategi. Pustaka Sinar Harapan. Jakarta.

Haji J. and Andersson H. 2007. Determinantsof efficiency of vegetable production of smallholder farms: the case of Ethiopia. Food Economics - Acta Agriculturae Scandinavica, Section C, 3:3, 125 - 137.

Hall A. 2006. Public private sector partnerships in an agricultural system of innovation: Concepts and challenges. UNU-MERIT Working Paper. Maastricht, The Netherlands: United Nations University/Maastricht Economic and Social Research and Training Centre on Innovation and Technology.

[Kementan] Kementrian Pertanian Republik Indonesia. 2014. Populasi dan Produksi Peternakan di Indonesia. Jakarta.

[Pusdatin] Pusat Data dan Sistem Informasai Pertanian (ID). 2014. Analisis PDB Sektor Pertanian Tahun 2013. Jakarta.

[Pusdatin] Pusat Data dan Sistem Informasai Pertanian (ID). 2013. Buletin Konsumsi Pangan. Jakarta.

Pribadi KL. 2013. Analisis Pelaksanaan Kemitraan Ayam ras pedaging pada CV. Barokah dan Pendapatan antara Peternak Mitra dan Peternak Mandiri di Kabupaten Bogor [skripsi]. Bogor (ID) : Institut Pertanian Bogor. 
Situmorang GF. 2013. Analisis Usaha

Peternakan Broiler Pola Kemitraan

Dan Peternak Mandiri (Studi

Kasus pada PT Sur) [skripsi].

Medan (ID) : Universitas Sumatra

Utara.

Sumardjo, Sulaksana J, Darmono WA. 2004. Teori dan Praktik Kemitraaan Agribisnis. Depok (ID): Penebar Swadaya.

Susrusa, Zulkifli. 2006. Efektifitas Kemitraan pada Usahatani Tembakau Virginia di Kabupaten Lombok Tiimur. Universitas Udayana. Bali. 
Lampiran 1. Struktur Biaya Usahaternak Mitra Ayam Ras Pedaging (Per 1.000 Ekor)

\begin{tabular}{|c|c|c|c|c|c|c|}
\hline \multirow{2}{*}{ Uraian } & \multicolumn{2}{|c|}{ Skala I } & \multicolumn{2}{|c|}{ Skala II } & \multicolumn{2}{|c|}{ Skala III } \\
\hline & $\begin{array}{c}\text { Biaya } \\
\text { (Rp/1000 } \\
\text { ekor) } \\
\end{array}$ & $\%$ & $\begin{array}{c}\text { Biaya } \\
\text { (Rp/1000 } \\
\text { ekor) } \\
\end{array}$ & $\%$ & $\begin{array}{c}\text { Biaya } \\
\text { (Rp/1000 } \\
\text { ekor) } \\
\end{array}$ & $\%$ \\
\hline \multicolumn{7}{|l|}{ Biaya Tunai } \\
\hline DOC & 4405.56 & 27.51 & 4422.22 & 27.05 & 4300.00 & 26.53 \\
\hline Pakan & 8926.10 & 55.74 & 9190.51 & 56.22 & 9219.94 & 56.89 \\
\hline Obat cair & 575.99 & 3.60 & 573.94 & 3.51 & 594.08 & 3.67 \\
\hline Obat padat & 192.01 & 1.20 & 189.12 & 1.16 & 195.69 & 1.21 \\
\hline Vitamin & 22.42 & 0.14 & 27.31 & 0.17 & 28.85 & 0.18 \\
\hline Skim & 7.01 & 0.04 & 7.89 & 0.05 & 8.16 & 0.05 \\
\hline Detergen & 11.74 & 0.07 & 14.84 & 0.09 & 11.91 & 0.07 \\
\hline Formalin & 13.35 & 0.08 & 13.14 & 0.08 & 14.02 & 0.09 \\
\hline Sekam & 148.17 & 0.93 & 149.56 & 0.91 & 152.86 & 0.94 \\
\hline Kayu bakar & 185.94 & 1.16 & 234.61 & 1.44 & 235.19 & 1.45 \\
\hline Kapur & 17.06 & 0.11 & 15.64 & 0.10 & 15.63 & 0.10 \\
\hline Listrik & 97.78 & 0.61 & 54.74 & 0.33 & 41.96 & 0.26 \\
\hline PBB & 1.81 & 0.01 & 1.31 & 0.01 & 1.46 & 0.01 \\
\hline TKLK & 0.00 & 0.00 & 0.00 & 0.00 & 0.00 & 0.00 \\
\hline Total biaya tunai & 15402.36 & 96.18 & 15693.09 & 95.99 & 15646.54 & 96.54 \\
\hline \multicolumn{7}{|l|}{ Biaya diperhitungkan } \\
\hline Sewa lahan & 84.27 & 0.53 & 90.29 & 0.55 & 68.86 & 0.42 \\
\hline Pnyusutn.kandng & 123.19 & 0.77 & 15466 & 0.95 & 96.01 & 0.59 \\
\hline Penyusutan alat & 54.68 & 0.34 & 60.01 & 0.37 & 45.29 & 0.28 \\
\hline TKDK & 350.00 & 2.19 & 350.00 & 2.14 & 350.00 & 2.16 \\
\hline Total b. diprhtngkn & 612.14 & 3.82 & 654.95 & 4.01 & 560.16 & 3.46 \\
\hline Total Biaya & 16014.51 & 100.00 & $\begin{array}{r}16 \\
348.04\end{array}$ & 100.00 & $\begin{array}{r}16 \\
474.74\end{array}$ & 100.00 \\
\hline
\end{tabular}


Lampiran 2. Struktur Biaya Usahaternak Mandiri Ayam Ras Pedaging (Per 1.000 Ekor)

\begin{tabular}{lcrrr}
\hline \multicolumn{1}{c}{ Uraian } & \multicolumn{1}{c}{ Skala II } & \multicolumn{2}{c}{ Skala III } \\
\cline { 2 - 5 } & $\begin{array}{c}\text { Biaya } \\
\text { (Rp/1000 } \\
\text { ekor) }\end{array}$ & \% & $\begin{array}{c}\text { Biaya } \\
\text { (Rp/1000 } \\
\text { ekor) }\end{array}$ & \% \\
\hline Biaya Tunai & & & & \\
DOC & 4066.67 & 24.68 & 4166.67 & 24.59 \\
Pakan & 9551.13 & 57.97 & 10086.57 & 59.54 \\
Obat cair & 617.28 & 3.75 & 521.60 & 3.08 \\
Obat padat & 220.56 & 1.34 & 225.09 & 1.33 \\
Vitamin & 51.15 & 0.31 & 5447 & 0.32 \\
Skim & 9.37 & 0.06 & 7.73 & 0.05 \\
Detergen & 13.47 & 0.08 & 13.50 & 0.08 \\
Formalin & 802 & 0.05 & 8.59 & 0.05 \\
Sekam & 124.50 & 0.76 & 122.20 & 0.72 \\
Kayu bakar & 256.64 & 1.56 & 271.67 & 1.60 \\
Kapur & 14.30 & 0.09 & 14.36 & 0.08 \\
Listrik & 57.56 & 0.35 & 47.50 & 0.28 \\
PBB & 1.31 & 0.01 & 1.37 & 0.01 \\
TKLK & 186.89 & 1.13 & 290.21 & 1.71 \\
Total biaya tunai & 1677.19 & 97.59 & 16640.42 & 98.22 \\
\hline Biaya diperhitungkan & & & & \\
Sewa lahan & 78.91 & 0.48 & 79.97 & 0.47 \\
Penyusutan kandang & 104.67 & 0.64 & 110.31 & 0.65 \\
Penyusutan alat & 50.87 & 0.31 & 51.23 & 0.30 \\
TKDK & 163.11 & 0.99 & 59.79 & 0.35 \\
Total biaya diperhitungkan & 397.55 & 2.41 & 301.29 & 1.78 \\
\hline Total Biaya & 16474.74 & 100.00 & 16941.72 & 100.00 \\
\hline & & & &
\end{tabular}

Lampiran 3. Produksi Rata-Rata Usahaternak Ayam Ras Pedaging (per 1.000 ekor)

\begin{tabular}{crrrrr}
\hline \multirow{2}{*}{ Ukuran (kg) } & \multicolumn{3}{c}{ Peternak Mitra } & \multicolumn{2}{c}{ Peternak Mandiri } \\
\cline { 2 - 6 } & Skala I & \multicolumn{1}{c}{ Skala II } & Skala III & Skala II & \multicolumn{1}{c}{ Skala III } \\
\hline $0.8-1.0$ & 149.43 & 209.67 & 195.29 & 311.43 & 338.17 \\
$1.0-1.2$ & 154.58 & 224.17 & 267.79 & 242.16 & 206.91 \\
$1.2-1.4$ & 308.54 & 282.25 & 175.45 & 122.90 & 101.43 \\
$1.4-1.6$ & 227.74 & 170.21 & 193.40 & 94.31 & 117.04 \\
$1.6-1.8$ & 239.13 & 200.47 & 169.54 & 106.88 & 132.65 \\
$1.8-2.0$ & 143.07 & 82.25 & 146.48 & 209.70 & 118.72 \\
$>2,0$ & 85.00 & 41.24 & 122.39 & 99.20 & 163.43 \\
\hline Total & 1307.49 & 1210.25 & 1270.35 & 1186.58 & 1178.35 \\
\hline
\end{tabular}


Lampiran 4. Penerimaan Total Usahaternak Ayam Ras Pedaging (per 1.000 ekor)

\begin{tabular}{lrrrrr}
\hline \multirow{2}{*}{ Uraian } & \multicolumn{3}{c}{$\begin{array}{c}\text { Peternak Mitra } \\
\text { (Rp 000) }\end{array}$} & \multicolumn{2}{c}{$\begin{array}{c}\text { PeternakMandiri } \\
(\text { Rp 000) }\end{array}$} \\
\cline { 2 - 6 } & \multicolumn{1}{c}{ Skala I } & \multicolumn{1}{c}{ Skala II } & Skala III & \multicolumn{1}{c}{ Skala II } & \multicolumn{1}{c}{ Skala III } \\
\hline Penerimaan tunai & & & & & \\
$\quad$ Penjualan ayam & 22519.22 & 20944.39 & 21793.07 & 20529.69 & 20502.05 \\
$\quad$ Penjualan kotoran & 291.67 & 505.56 & 433.33 & 566.67 & 716.67 \\
Total penerimaan tunai & 22810.89 & 21449.95 & 22226.40 & 21096.36 & 21218.72 \\
Peneriman diprhtgkn & & & & & \\
$\quad$ Hasil yg dikonsumsi & 0.00 & 0.00 & 0.00 & 66.97 & 68.49 \\
Total penerimaan & 22810.89 & 21449.96 & 22226.40 & 21163.32 & 21287.21 \\
\hline
\end{tabular}

Lampiran 5. Pendapatan dan R/C Rasio Usahaternak Ayam Ras Pedaging (per 1.000 ekor)

\begin{tabular}{lrrrrr}
\hline \multirow{1}{*}{ Uraian } & \multicolumn{3}{c}{$\begin{array}{c}\text { Peternak Mitra } \\
\mathbf{( R p ~ 0 0 0 )}\end{array}$} & \multicolumn{2}{c}{$\begin{array}{c}\text { Peternak Mandiri } \\
\text { (Rp 000) }\end{array}$} \\
\cline { 2 - 7 } & \multicolumn{1}{c}{ Skala I } & \multicolumn{1}{c}{ Skala II } & \multicolumn{1}{c}{ Skala III } & \multicolumn{1}{c}{ Skala II } & \multicolumn{1}{c}{ Skala III } \\
\hline Penerimaan tunai & 22349.04 & 21421.71 & 22062.35 & 21096.36 & 21089.41 \\
Penerimaan diprhitngkan & 0.00 & 0.00 & 0.00 & 6696 & 68.49 \\
Penerimaan total & 22349.04 & 21421.71 & 22062.35 & 21163.32 & 21157.91 \\
Biaya tunai & 14604.93 & 14894.83 & 14819.76 & 15225.28 & 15891.32 \\
Biaya diperhitungkan & 612.14 & 654.95 & 560.16 & 428.26 & 329.62 \\
Biaya total & 15217.08 & 15549.78 & 15379.92 & 15653.54 & 16220.94 \\
Pendapatan a/ b. tunai & 7744.11 & 6526.89 & 7242.59 & 5938.04 & 526659 \\
Pendapatan a/ b. total & 7131.96 & 5871.94 & 6682.43 & 5526.14 & 4986.36 \\
R/C rasio atas b.tunai & 1.53 & 1.44 & 1.49 & 1.39 & 1.33 \\
R/C rasio atas b. total & 1.47 & 1.38 & 1.43 & 1.35 & 1.31 \\
\hline
\end{tabular}

